\title{
Changes in leaf nutrient content and quality of pear fruits by biofertilizer application in northeastern Italy
}

\author{
Barbara Elen Perazzoli ${ }^{1}$, Volnei Pauletti ${ }^{2}$, Maurizio Quartieri ${ }^{3}$, \\ Moreno Toselli ${ }^{4}$, Lenir Fátima Gotz
}

\begin{abstract}
The aim of this study was to verify the influence of biofertilizer application resulting from energy production from corn biomass on nutrient uptake by pear plants during the growing cycle, and on fruit quality. The experiment was carried out on a Siltic Haplic Calcisol in the Italian province of Ferrara, in a medium-density Abbé Fétel commercial orchard. Treatments consisted of control (no application) and biofertilizer $\left(30 \mathrm{~m}^{3} \mathrm{ha}^{-1}\right.$ biofertilizer application on the row), with four replicates. The following variables were evaluated: mineral $\mathrm{N}$, microbial biomass and respiration in soil; nutrient content in leaves; and fruit quality. Biofertilizer application increased soil mineral $\mathrm{N}$ availability; soil microbial biomass and respiration, but the content of this nutrient did not increase in leaves. Leaf nutrient concentration varied during growth season and biofertilizer application increased potassium, phosphorus and zinc concentration in mature leaves and reduced leaf magnesium and manganese concentration. Biofertilizer application reduced fruit dry matter content, total soluble solids and boron concentration, with no effect on fruit firmness and titratable acidity. Biofertilizer application has positive effect on soil mineral $\mathrm{N}$ dynamics and soil microflora, altering the content of nutrients in leaves, favoring fruit production.

Index terms: Soil nitrate. Pyrus communis. Organic fertilization. Biodigester effluent. Corn biomass biofertilizer.

\section{Alteração do teor foliar de nutrientes e qualidade dos frutos de pera pela aplicação de biofertilizante no nordeste da Itália}

Corresponding author: barbara@agropel.com.br

Received: July 26, 2019 Accepted: January 13, 2020

Copyright: All the contents of this journal, except where otherwise noted, is licensed under a Creative Commons Attribution License.

\section{(cc) $\mathbf{E Y}$}

Resumo-O objetivo foi verificar a influência da aplicação de biofertilizante resultante da produção de energia a partir de biomassa de milho na absorção de nutrientes por plantas de pera durante o ciclo de cultivo, e na qualidade dos frutos. O experimento foi realizado em Ferrara (Itália), num pomar da cv. Abate Fétel, sobre Calcisolo Síltico Háplico. Os tratamentos consistiram em controle (sem aplicação) e biofertilizante (aplicação de $30 \mathrm{~m}^{3} \mathrm{ha}^{-1}$ de biofertilizante, localizada na fila), com quatro repetições. Foram avaliados: N mineral, biomassa e respiração microbiana no solo; teor de nutrientes em folhas; e parâmetros de qualidade dos frutos. A aplicação de biofertilizante aumentou a disponibilidade de $\mathrm{N}$ mineral, a biomassa e respiração microbianas, e mesmo assim o teor deste nutriente não aumentou nas folhas. Os teores dos nutrientes foliares variaram durante a estação de crescimento e a aplicação de biofertilizante aumentou os teores de potássio, fósforo e zinco nas folhas maduras; enquanto reduziu o teor de magnésio e manganês foliar. A aplicação de biofertilizante reduziu o teor de massa seca, de sólidos totais e de boro dos frutos, sem efeito na firmeza e na acidez titulável. O biofertilizante teve efeito positivo sobre a dinâmica do $\mathrm{N}$ mineral no solo e a microbiota edáfica, alterando o teor de nutrientes nas folhas, favorecendo a produção de frutos.

Termos de indexação: Nitrato no solo. Pyrus communis. Adubação orgânica. Resíduo de biodigestor. Biofertilizante de biomassa de milho.

\footnotetext{
${ }^{1}$ Agronomist, Technical Assistant - AGROPEL Agroindustrial Perazzoli Ltda, Fraiburgo, Santa Catarina, Brazil. E-mail: barbara@agropel.com. br (ORCID: 0000-0002-5241-3275)

${ }^{2}$ Agronomist, PhD, Associate Professor - Federal University of Paraná, Curitiba, Paraná, Brazil. E-mail: vpauletti@ufpr.br ${ }^{\text {(ORCID: } 0000-0002-}$ 9231-7851)

${ }^{3}$ Agronomist, MSc, Laureate Technician - University of Bologna, Bologna, Emilia Romagna, Italy. E-mail: maurizio.quartieri@unibo. it (ORCID:0000-0003-2476-0541)

${ }^{4}$ Agronomist, PhD, Associate Professor - University of Bologna, Bologna, Emilia Romagna, Italy. E-mail: moreno.toselli@unibo.it ${ }^{\text {(ORCID: }}$ 0000-0001-5632-6331)

5. Agronomist, MSc - Federal University of Paraná, Curitiba, Paraná, Brazil. E-mail: lenirgotz@gmail.com ${ }^{\text {(ORCID: 0000-0001-6145-4717) }}$
} 


\section{Introduction}

Nitrogen fertilization is an important tool to increase orchard yield (CARRANCA et al., 2018). However, the importance of this nutrient has led to a great increase in fertilizer use; for example, in 2010, global use was more than one hundred million metric tons of nitrogen fertilizer. Furthermore, analyses based on past trends, methods, and practices estimate that a $170 \%$ increase in nitrogen fertilization might be required to double global food production by 2050 (TILMAN; CLARK, 2015).

However, it is known that the excessive application of mineral and synthetic fertilizers in intensive farming systems has led to nutrient accumulation in soils and groundwater, which is responsible for a decrease of soil organic matter (OM) (SVANBÄCK et al., 2019; OMARA et al., 2019). Nardi et al. (2004) verified that only farmyard manure fertilization maintained total organic carbon level of $40 \mathrm{t} \mathrm{C} \mathrm{ha}^{-1}$, measured in topsoil layers at the start of a 40-year experiment, while the average total organic $\mathrm{C}$ depletion was $43 \%$ with mineral fertilizers. In a ricewheat system, farmyard manure application at $20 \mathrm{tha}^{-1}$ showed, after a period of 32 years, higher organic carbon concentration of $17 \%$ compared with NPK fertilizers in the $0-15 \mathrm{~cm}$ soil layer (KUKAL et al., 2009). In addition, losses of $\mathrm{N}$ and phosphorus (P) may decrease the water quality of rivers and lakes through the eutrophication process, resulting in an important problem (VOLK et al., 2009; NIE et al., 2018).

In this context, an alternative to the use of synthetic or mineral fertilizers is the application of organic materials as nutrient source. Increased soil organic matter $(\mathrm{OM})$ content plays an important role in longterm soil fertility preservation, due to the improvement of its physical, chemical and biological properties (HAYNES, 2005; DĘBSKA et al., 2016; OLDFIELD et al., 2018; CIHANGIR; OKTEM, 2019). However, most agricultural soils of the Eastern part of the Po Valley in Italy have shown OM concentration often lower than 1.5\% (UNGARO et al., 2002), due to the reduced availability of organic fertilizers and increasing farm specialization.

Thus, there is growing interest in the use of biodigester effluents (known as biofertilizers) in agriculture to provide nutrients as an alternative to mineral fertilizers (RAHEEM et al., 2016; DĘBSKA et al., 2016; VERONEZE et al., 2019). They are byproducts of the anaerobic digestion of organic materials, whose major purpose is the production of electricity and/or heat through combustion of the main product, biogas (TAMBONE et al., 2009; OLIVEIRA et al., 2011). These products have all the necessary elements for plant nutrition, varying concentrations according to the preparation method and the originating material (MARROCOS et al., 2012). In a literature review, Möller and Müller (2012) highlighted values ranging from 1.2-11.5, 1.2-9.1, 0.4-2.6, 1.0-2.3, 0.3-0.7 and $0.2-0.4 \mathrm{~kg} \mathrm{Mg}^{-1}$ fresh matter for total $\mathrm{K}$, total $\mathrm{N}$, total $\mathrm{P}$, total $\mathrm{Mg}$ and total $\mathrm{S}$ in residual anaerobic digestion product. Veroneze et al. (2019) verified that micronutrient concentrations are quite significant for plant fertilization, and the biofertilizer evaluated is a good alternative for the supply of $\mathrm{Cu}, \mathrm{Zn}, \mathrm{Fe}$ and $\mathrm{Mn}$ for plants. However, there is lack of information about its use in well-established plantations.

Based on the above, the aim of this study was to verify the influence of biofertilizer application resulting from energy production from corn biomass on nutrient uptake by pear plants during the growing cycle and on fruit quality.

\section{Materials and methods}

\section{Experimental site characteristics}

This study was carried out in 2014 in a commercial farm in the province of Ferrara $\left(44^{\circ} 48^{\prime} 03\right.$ "N; 11 39'02" E), in the Emilia-Romagna region, northeastern Italy. The local climate can be defined as Cfb-humid temperate, according to the Köppen system updated by Peel et al. (2007). According to the survey carried out by the Servizio Geologico, Sismico e dei Suoli (2013), the local soil is a Siltic Haplic Calcisol in the FAO classification (1988). It presented the following characteristics (in the $0-40 \mathrm{~cm}$ depth): Sand: $26 \%$; Silt: 46\%; Clay: $28 \%$; $\mathrm{pH}_{(\mathrm{H} 2 \mathrm{O})} 7.6$; Organic Carbon: $14 \mathrm{~g} \mathrm{dm}^{-3}$; Total N: $1.8 \mathrm{~g} \mathrm{dm}^{-3}$; Olsen P: $22.4 \mathrm{mg} \mathrm{dm}^{-3}$; K: $0.5 \mathrm{cmol}_{\mathrm{c}}$ $\mathrm{dm}^{-3}$; Ca: $13.0 \mathrm{cmol}_{\mathrm{c}} \mathrm{dm}^{-3} ; \mathrm{Mg}: 2.8 \mathrm{cmol}_{\mathrm{c}} \mathrm{dm}^{-3} ; \mathrm{H}+\mathrm{Al}$ : $0.0 \mathrm{cmol}_{\mathrm{c}} \mathrm{dm}^{-3}$; CEC (Cation Exchange Capacity): 16.3 $\mathrm{cmol}_{\mathrm{c}} \mathrm{dm}^{-3}$; SOB (Sum of Bases): $16.3 \mathrm{cmol}_{\mathrm{c}} \mathrm{dm}^{-3}$; BS (Base Saturation): 100\%.

The experimental field was a 12-year old European pear orchard (Pyrus communisL.) Abbé Fétel cultivar grafted onto Farold ${ }^{\circledR} 40$ rootstock. Spacing was $3.8 \mathrm{~m}$ between rows and $1.5 \mathrm{~m}$ in the row, amounting to 1,754 plants $\mathrm{ha}^{-1}$ (medium density). The training system was in free palmette. The orchard was equipped with a drip irrigation system. Soil was kept covered throughout the year by spontaneous vegetation, controlled by periodic cuts. Integrated production was adopted, following the rules of the Regione Emilia-Romagna (2013).

\section{Experimental design and biofertilizer characteristics}

The experimental design was completely randomized, consisting of two treatments with four replicates each. Each plot had 20 plants. Treatments were: control (no application) and biofertilizer $\left(30 \mathrm{~m}^{3}\right.$ ha $^{-1}$ application of biodigester effluent). 
The liquid biofertilizer used in this experiment was provided by Palmirano Biogas Società Agricola (Ferrara, Italy), and was a residue of the anaerobic digestion of corn biomass to produce biogas. Biofertilizer was applied on June $2^{\text {nd }}, 2014$, when pear fruits had about $30 \mathrm{~mm}$ in diameter using a liquid organic fertilizer distributor, locating the product on a strip about $1 \mathrm{~m}$ in width $(0.5 \mathrm{~m}$ on each side) along the row. The product amount to be applied was defined according to limits set in the rules for integrated production (REGIONE EMILIA-ROMAGNA, 2013). No other fertilizer was applied during the season.

The biofertilizer main characteristics can be verified in Table1. It is relatively rich in $\mathrm{N}$, presenting considerable amounts of other macronutrients and micronutrients, and low concentration of heavy metals - barium $(\mathrm{Ba})$, chromium $(\mathrm{Cr})$, lead $(\mathrm{Pb})$, cobalt $(\mathrm{Co})$, and cadmium $(\mathrm{Cd})$.

Table 1 - Chemical characteristics of biofertilizer and total applied by element.

\begin{tabular}{cccccccc}
\hline Parameter & Unit & Result & $\begin{array}{c}\text { Total } \\
\left(\mathrm{kg} \mathrm{ha}^{-1}\right)\end{array}$ & Parameter & Unit & Result & $\begin{array}{c}\text { Total } \\
\left(\mathrm{g} \mathrm{ha}^{-1}\right)\end{array}$ \\
\hline $\begin{array}{c}\text { DH matter } \\
\text { Dry ma }\end{array}$ & - & 7.8 & - & $\mathrm{Zn}$ & $\mathrm{mg} \mathrm{kg}^{-1}$ & 243.2 & 591 \\
$\mathrm{C}$ & $\mathrm{g} \mathrm{kg}^{-1}$ & 375.0 & 9,430 & $\mathrm{Mn}$ & $\mathrm{mg} \mathrm{kg}^{-1}$ & 186.7 & 454 \\
$\mathrm{~N}$ & $\mathrm{~g} \mathrm{~kg}^{-1}$ & 31.3 & 76 & $\mathrm{Cu}$ & $\mathrm{mg} \mathrm{kg}^{-1}$ & 120.6 & 293 \\
$\mathrm{Ca}$ & $\mathrm{g} \mathrm{kg}^{-1}$ & 16.4 & 40 & $\mathrm{Ba}$ & $\mathrm{mg} \mathrm{kg}$ & 36.9 & 90 \\
$\mathrm{P}$ & $\mathrm{g} \mathrm{kg}^{-1}$ & 8.4 & 20 & $\mathrm{~B}$ & $\mathrm{mg} \mathrm{kg}$ & 31.7 & 77 \\
$\mathrm{Mg}$ & $\mathrm{g} \mathrm{kg}^{-1}$ & 7.8 & 19 & $\mathrm{Ni}$ & $\mathrm{mg} \mathrm{kg}^{-1}$ & 13.7 & 33 \\
$\mathrm{~K}$ & $\mathrm{~g} \mathrm{~kg}^{-1}$ & 7.4 & 18 & $\mathrm{Cl}$ & $\mathrm{mg} \mathrm{kg} \mathrm{k}^{-1}$ & 7.9 & 19 \\
$\mathrm{~S}$ & $\mathrm{~g} \mathrm{~kg}^{-1}$ & 3.8 & 9 & $\mathrm{Mo}$ & $\mathrm{mg} \mathrm{kg}^{-1}$ & 6.4 & 16 \\
$\mathrm{Na}$ & $\mathrm{g} \mathrm{kg}^{-1}$ & 2.4 & 6 & $\mathrm{~Pb}$ & $\mathrm{mg} \mathrm{kg}^{-1}$ & 4.7 & 16 \\
$\mathrm{Fe}$ & $\mathrm{g} \mathrm{kg}^{-1}$ & 1.7 & 4 & $\mathrm{Co}$ & $\mathrm{mg} \mathrm{kg}^{-1}$ & 0.5 & 1 \\
$\mathrm{Al}$ & $\mathrm{g} \mathrm{kg}^{-1}$ & 1.0 & 2 & $\mathrm{Cd}$ & $\mathrm{mg} \mathrm{kg}^{-1}$ & 0.4 & 1 \\
\hline
\end{tabular}

${ }^{1}$ Source: Laboratory of Biochemistry, Department of Agricultural Sciences, University of Bologna (2014).

\section{Soil analysis}

Mineral $\mathrm{N}$ (ammonium $-\mathrm{NH}_{4}^{+}-\mathrm{N}$ and nitric- $\mathrm{NO}_{3}^{-}$ -N) soil concentration was measured through periodic sampling $(1,8,30,90,120,150$ and 180 days after biofertilizer application -DAA) in the profile from 5 to $60 \mathrm{~cm}$ in depth ( 5 to $30 \mathrm{~cm}$ and $31 \mathrm{~cm}$ to $60 \mathrm{~cm}$ ). The first $5 \mathrm{~cm}$ were discarded to eliminate crop litter interference in the analysis (BOONE et al., 1999).

Soil samples were homogenized and sieved (2 $\mathrm{mm}$ mesh). About $100 \mathrm{~mL}$ of a $2 \mathrm{~mol} \mathrm{~L}^{-1}$ potassium chloride ${ }^{(\mathrm{KCl})}$ extractive solution was added to $10 \mathrm{~g}$ moist soil samples. After stirring for $1 \mathrm{~h}$ at $110 \mathrm{rpm}$ and filtering, the resulting solution was frozen at $-20{ }^{\circ} \mathrm{C}$ for storage until further analysis. $\mathrm{NO}_{3}^{-}-\mathrm{N}$ and $\mathrm{NH}_{4}^{+}-\mathrm{N}$ concentrations were measured using automatic continuous flow analyzer (AA-3 Auto Analyzer; Bran + Luebbe, Norderstadt, Germany). Soil sub-sample was oven-dried at $105{ }^{\circ} \mathrm{C}$ until constant weight to determine moisture content.

Soil mineral $\mathrm{N}$ availability (in $\mathrm{kg} \mathrm{ha}^{-1}$ ) was estimated considering depth from 5 to $60 \mathrm{~cm}$; width of $0.5 \mathrm{~m}$ on each side of the row under plants (therefore, it was not calculated on the total area, only in the row); and soil bulk density of $1,400 \mathrm{~kg} \mathrm{~m}^{-3}$. This value is common to the region, as cited by Ventura et al. (2013), who analyzed similar soil.
Microbial biomass and respiration analyses were performed as described by Anderson and Domsch (1978), adapted from Jenkinson and Powlson (1976). Soil samples from 5 to $15 \mathrm{~cm}$ in depth were taken from plot in three dates: Oct. $2^{\text {nd }}(120$ DAA $)$, Nov. $4^{\text {th }}(150$ DAA $)$ and Dec. $10^{\text {th }}, 2014$ (180 DAA). After being homogenized and sieved to remove plant debris and other materials, $50 \mathrm{~g}$ of moist soil from each sample were placed in glass jars and left under damp cloth overnight to standardize relative humidity inside jars. On the following day, 200 $\mathrm{mg}$ of D-glucose were added to each sample, which were then homogenized and hermetically sealed at equal three-minute intervals. After incubation for three hours, the carbon dioxide $\left(\mathrm{CO}_{2}\right)$ concentration in the jar head space was read using infrared $\mathrm{CO}_{2}$ analyzer EGM-4 (PP Systems, Amesbury, USA). The following data have been recorded: initial peak $\left(\mathrm{t}_{0}=0 \mathrm{~min}\right)$, lowest value $\left(\mathrm{t}_{1} \approx 1 \mathrm{~min}\right)$ and value presented 1 min after the previous one $\left(t_{2} \approx 2\right.$ $\mathrm{min})$ at regular 3-min intervals. Thereby, the difference between $t_{1}$ and $t_{2}\left(\Delta \mathrm{CO}_{2}\right)$ was obtained, corresponding to the amount of $\mathrm{CO}_{2}$ produced by microorganisms in the considered time. Regression equation was then used to calculate the $\mathrm{CO}_{2}$ rate produced per unit of time (in ppm $\mathrm{CO}_{2} \mathrm{~h}^{-1}$ ) and the amount of microbial biomass (in $\mu \mathrm{g} \mathrm{C}$ $\mathrm{g}^{-1}$ of soil), according to Anderson and Domsch (1978). 


\section{Plant analysis}

From each plot, samples of 20 mature, expanded, and healthy leaves were taken from shoots on the middle third of the canopy in July (summer - mature leaves, 30 DAA) and October (autumn - before senescence started, 120 DAA). After this procedure, nets were placed around a few branches in each plot to enable the collection of leaves during their natural abscission in November and December (winter - post-abscission, 150 and 180 DAA). Total leaf area was measured using portable area meter (Li-3000, LiCorInc., Lincoln, Nebraska). Leaves were then washed in $\mathrm{HCl}\left(0.1 \mathrm{~mol} \mathrm{~L}^{-1}\right)$ and surfactant (Tween $20 ®)(0.1 \%)$ solution according to Álvarez-Fernández et al. (2001), rinsed in tap and distilled water, oven-dried at $60{ }^{\circ} \mathrm{C}$ until constant weight, weighed, and milled. Each sample was mineralized according to US EPA Methods 3052 (KINGSTON, 1988): sub-samples weighing $0.5 \mathrm{~g}$ were placed in special containers added of $8 \mathrm{~mL}$ of $65 \%$ nitric acid $\left(\mathrm{HNO}_{3}\right)$ and $2 \mathrm{~mL}$ of $30 \%$ hydrogen peroxide $\left(\mathrm{H}_{2} \mathrm{O}_{2}\right)$. Once sealed, containers were placed in microwave lab station (Ethos TC, Milestone, Bergamo, Italy) at 180 ${ }^{\circ} \mathrm{C}$ for $20 \mathrm{~min}$. Then, samples were analyzed using optical emission spectrophotometry with inductively coupled plasma (ICP) (Ametek Spectro, Arcos, Kleve, Germany) to determine the following nutrients: $\mathrm{P}, \mathrm{K}, \mathrm{Ca}, \mathrm{Mg}, \mathrm{S}$, $\mathrm{Cu}, \mathrm{Zn}, \mathrm{B}, \mathrm{Mn}$ and $\mathrm{Fe}$. N concentration was obtained by the Kjeldahl method, adapted by Schuman et al. (1973). Dry leaf sub-samples weighing $0.5 \mathrm{~g}$ were mineralized with $14 \mathrm{~mL}$ of 95:5 (v/v) sulfuric acid $\left(\mathrm{H}_{2} \mathrm{SO}_{4} 95 \%\right)$ and phosphoric acid $\left(\mathrm{H}_{3} \mathrm{PO}_{3} 85 \%\right)$ solution, at $420{ }^{\circ} \mathrm{C}$ for $3 \mathrm{~h}$; distilled with $32 \%(\mathrm{v} / \mathrm{v})$ sodium hydroxide $(\mathrm{NaOH})$ and titrated with $0.2 \mathrm{~mol} \mathrm{~L}^{-1} \mathrm{HCl}$.

Commercial harvest was on September $3^{\text {rd }}, 2014$ (90 DAA); total yield per treatment was measured, and fruits that reached base diameter of $65 \mathrm{~mm}$ or more were considered commercial. For each plot, samples of 16 fruits were collected, weighed, and submitted to the following qualitative assessments:

- Fruit firmness: measured using penetrometer with 8-mm plunger (Effegi, Ravenna, Italy), and expressed in $\mathrm{kg}$;

- Total soluble solids (TSS): measured using portable digital refractometer PR-1 (Atago, Tokyo, Japan) and expressed in ${ }^{\circ}$ Brix;

- Titratable acidity: measured using automatic titrator Compact Titrator (Crison, Barcelona, Spain), and expressed in $\mathrm{g} \mathrm{L}^{-1}$ of malic acid equivalent.

Pulp dry matter content was obtained removing the peel and oven-drying sub-samples at $65{ }^{\circ} \mathrm{C}$ until constant weight. To obtain fruit mineral concentration, fruit sub-samples were lyophilized, milled, mineralized and analyzed according to methods previously described for leaf analysis.
Data were submitted to analysis of variance using the SAS/STAT statistical software (Cary, USA), and the SNK test (Student-Newman-Keuls, $p=0.05$ ) for separation.

\section{Results and discussion}

\section{Soil analysis}

Soil moisture content was higher with biofertilizer application in five of the seven dates throughout the monitoring period (Figure 1A). Soil moisture in treated plots was $22 \%$ higher than control at $150 \mathrm{DAA}$, and $14 \%$ higher at $180 \mathrm{DAA}$, indicating that this was a long-lasting effect. This result may be due to the improvement in water retention with biofertilizer application, as verified by Alencar et al. (2015). In addition, the mulch effect of the biofertilizer may have contributed to this increase in moisture, locally decreasing evaporation rate and contributing to save soil water, which is important mainly because it is an irrigated area (LAL, 2009; JORDÁN et al., 2010). This effect is probably not due to the increase in inorganic matter content, since successive applications would be necessary, and in this case only one application was carried out (LOURENZI et al., 2016). Soil $\mathrm{NO}_{3}^{-}-\mathrm{N}$ concentration increased by biofertilizer application, and this effect was rapid, since it was already detected at 8 DAA (Figure 1B). Moreover, it proved to be lasting, because important differences were demonstrated up to 150 DAA.

In untreated soil, $\mathrm{NO}_{3}^{-}-\mathrm{N}$ concentration decreased during the intensive shoot growth phase, when plant demand for $\mathrm{N}$ is high (June and July - 8 and 30 DAA). The increased $\mathrm{NO}_{3}^{-}-\mathrm{N}$ concentration at 90 DAA may be due to mineralization of OM naturally present in the soil enhanced by high temperatures and rainfall that occurred in the summer (130 mm of rain in July and August) combined with low root uptake rate at that time (SUGAR et al., 1992; QUARTIERI et al., 2002).

$\mathrm{NO}_{3}{ }^{-} \mathrm{N}$ is mobile and susceptible to loss due to leaching due to its low adsorption to soil particles (NAZ; SULAIMAN, 2016). Therefore, biofertilizer application provided synchronization of $\mathrm{N}$ supply according to plant demand, avoiding mineral $\mathrm{N}$ accumulation in the soil, and consequently, risk of $\mathrm{NO}_{3}^{-}-\mathrm{N}$ leaching (DIACONO; MONTEMURRO, 2010).

Soil $\mathrm{NH}_{4}^{+}-\mathrm{N}$ concentration did not increase during the evaluation period, except in analysis carried out at 180 DAA (Figure 1C). Probably, most $\mathrm{NH}_{4}^{+}$added to the soil by the biofertilizer was rapidly oxidized to $\mathrm{NO}_{3}{ }^{-}$through the nitrification process performed by chemosynthetic bacteria (DI et al., 2009; MINOGUE et al., 2012), contributing to increase the $\mathrm{NO}_{3}{ }^{-}$concentration in the soil solution. In addition, there may have been loss of $\mathrm{NH}_{4}^{+}-\mathrm{N}$ by volatilization (loss to the atmosphere in 
the form of ammonia gas $-\mathrm{NH}_{3}$ ), which occurs when it is in solution at neutral or alkaline $\mathrm{pH}$ (ROCHETTE et al., 2013), as is the case of the experimental site $\left(\mathrm{pH} \mathrm{H}_{2} \mathrm{O}\right.$ : 7.6).

Total mineral soil $\mathrm{N}$ availability was higher in treated plots, as compared to those untreated in almost all analyzed dates (Figure 1D). At 30 DAA, N availability was five times higher in treated plots, and almost double at 120 and 150 DAA, while at 180 DAA, this difference disappeared. However, the increase in mineral $\mathrm{N}$ availability was never equal to the amount of $\mathrm{N}$ provided by the biofertilizer, indicating that the nutrient remained in the 0-5 cm layer (not sampled) was absorbed by plants, lost by $\mathrm{NO}_{3}^{-}$leaching, $\mathrm{NH}_{3}$ volatilization, or denitrification.
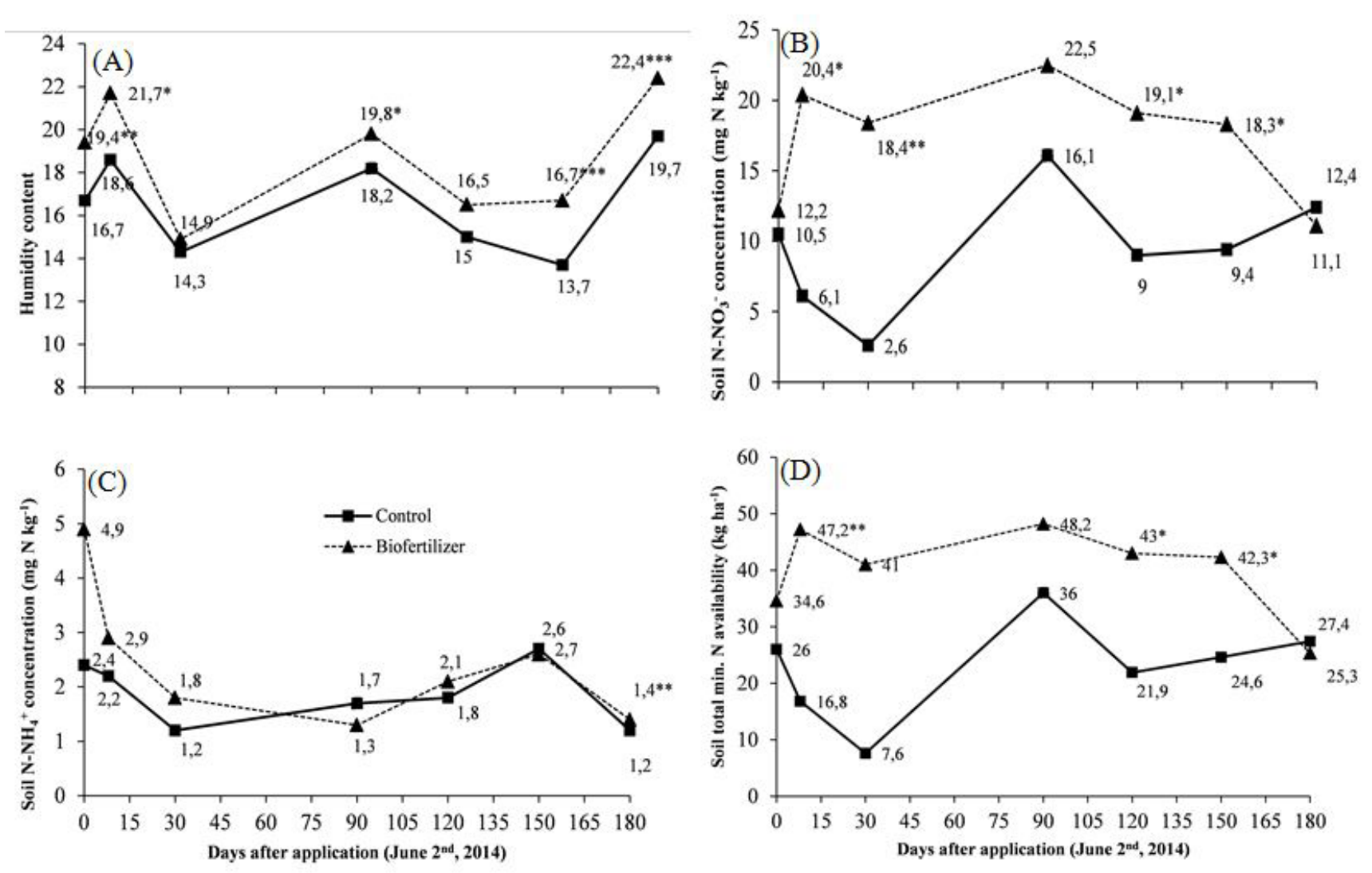

Figure 1. Effect of biofertilizer application on soil: $1 \mathrm{~A}-$ Moisture content; $1 \mathrm{~B}: \mathrm{NO}_{3}^{-}-\mathrm{N}$ concentration; $1 \mathrm{C}: \mathrm{NH}_{4}^{+}-\mathrm{N}$ concentration; 1D: Total Mineral $\mathrm{N}$ availability up to 180 days after application (average of $5-30 \mathrm{~cm}$ and $31-60 \mathrm{~cm}$ depths for $1 \mathrm{~A}, 1 \mathrm{~B}$ and $1 \mathrm{C}$ ). Soil $\mathrm{N}$ availability at $5-60 \mathrm{~cm}$ in depth.*, ** and ***: significant for $p<0.05, p<0.01$ and $p<0.001$, respectively.

\section{Microbial respiration and biomass}

The increase in soil $\mathrm{N}$ is linked to a consistent increase in microbial biomass, expressed by microbial $\mathrm{C}$, and activity (shown by $\mathrm{CO}_{2}$ produced in respiration), resulting from biofertilizer application (Table 2). This is due to the microbial biomass that acts as buffer of $\mathrm{N}$ in the soil, controlling the availability of this nutrient by means of mineralization and immobilization (BARRETO et al., 2008). Considering that the soil microflora feeds
Proper soil $\mathrm{N}$ availability during the growing season is important for the vegetative growth of pear trees. Although only about $10 \%$ of $\mathrm{N}$ allocated to fruits come from uptake in summer (June-August) (QUARTIERI et al., 2002), $\mathrm{N}$ absorbed at this time may be stored in the woody plant structures and remobilized the following spring for floral development (SUGAR et al., 1992), ensuring good budding and flowering in the following year. 
Table 2. Effect of biofertilizer application on soil microbial activity $(5-15 \mathrm{~cm}$ depth).

\begin{tabular}{ccccccc} 
& \multicolumn{2}{c}{ Oct. 2 $2^{\text {nd }} 2014$} & \multicolumn{2}{c}{ Nov. $4^{\text {th }} 2014$} & \multicolumn{2}{c}{ Dec. $10^{\text {th }} 2014$} \\
Treatment & \multicolumn{2}{c}{$120 \mathrm{DAA}$} & \multicolumn{2}{c}{$150 \mathrm{DAA}$} & \multicolumn{2}{c}{180 DAA } \\
& $\begin{array}{c}\text { Produced CO } \\
\mathrm{ppm} \mathrm{CO}_{2} \mathrm{~h}^{-1}\end{array}$ & $\begin{array}{c}\text { Microbial C } \\
\mu \mathrm{g} \mathrm{C} \mathrm{g}^{-1}\end{array}$ & $\begin{array}{c}\text { Produced CO } \\
\mathrm{ppm} \mathrm{CO}_{2} \mathrm{~h}^{-1}\end{array}$ & $\begin{array}{c}\text { Microbial C } \\
\mu \mathrm{g} \mathrm{C} \mathrm{g}^{-1}\end{array}$ & $\begin{array}{c}\text { Produced CO } \\
\mathrm{ppm} \mathrm{CO}_{2} \mathrm{~h}^{-1}\end{array}$ & $\begin{array}{c}\text { Microbial C } \\
\mu \mathrm{g} \mathrm{C} \mathrm{g}^{-1}\end{array}$ \\
\hline Control & 16 & 51 & 17 & 52 & 13 & 46 \\
Biofertilizer $^{1}$ & 26 & 86 & 22 & 72 & 21 & 75 \\
\hline Significance $^{2}$ & $*$ & $*$ & $* *$ & $* *$ & $*$ & $*$ \\
\hline
\end{tabular}

${ }^{1}$ Biofertilizer applied at $30 \mathrm{~m}^{3}$ ha ${ }^{-1}$ dose on June $2^{\text {nd }} 2014 .{ }^{2 *}$ and $* *$ : significant for $p<0.05$ and $p<0.01$, respectively.

Microbial $\mathrm{C}$ is an important soil quality attribute - acting as a nutrient reservoir and central C-cycle compartment - and is one of the most sensitive to changes caused by soil management practices (GAMARODRIGUES; GAMA-RODRIGUES, 2008; BALOTA, AULER, 2011). Its increase indicates improvement in soil quality - since microbial $\mathrm{C}$ is closely linked to total soil organic $\mathrm{C}$ (data not presented) (DIACONO; MONTEMURRO, 2010). It should be noted that microorganisms are the main agents of nutrient mineralization, being that about $90 \%$ of nutrients are mineralized by microorganisms, making them available in the soil solution and, consequently, in plants (LAVELLE, 2000).

\section{Leaf analysis}

Leaf area and dry weight, in both treatments, were strongly reduced between autumn and winter. Leaf area was higher in the beginning of senescence (on average $21.6 \mathrm{~cm}^{2}$ leaf $\left.{ }^{-1}\right)$ than at post absission $\left(14.9 \mathrm{~cm}^{2}\right.$ leaf $\left.^{-1}\right)$, as it was observed for leaf dry weight, which decreased from 241 to $156 \mathrm{mg} \mathrm{leaf}^{-1(-35 \%)}$. Meanwhile, specific leaf weight (SLW) remained unchanged (on average 10.8 $\mu \mathrm{g} \mathrm{cm}^{-2)}$. In deciduous tree species, SLW shows initial increase with increasing leaf age until completion of leaf structural differentiation and then remain constant or moderately increases or decreases with further increases in leaf age (NIINEMETS, 2016). These variations in leaf dry mass per area unit (SLW) and nutrient content per dry mass affect the amount of nutrient removed by the tree canopy.

In both treatments, nutrient concentration in mature pear leaves (Table 3), with exception were $\mathrm{Fe}$ and $\mathrm{Cu}$, was mostly within the normal range expected for the season for Abbé Fétel grown in Emilia-Romagna (TOSELLI et al., 2002). According to Toselli et al. (2002), the optimal $\mathrm{Fe}$ and $\mathrm{Cu}$ concentration in mature pear leaves is 60$95 \mathrm{mg} \mathrm{kg}^{-1}$ and $25-50 \mathrm{mg} \mathrm{kg}^{-1}$, respectively. Thus, $\mathrm{Fe}$ concentration was lower $\left(33 \mathrm{mg} \mathrm{kg}^{-1}\right.$ - control and 39 mg kg-1 - biofertilizer) and $\mathrm{Cu}$ concentration was much higher than expected $\left(118 \mathrm{mg} \mathrm{kg}^{-1}\right.$ - control and 121 $\mathrm{mg} \mathrm{kg}^{-1}$ - biofertilizer) (Table 3 ). $\mathrm{K}$ concentration was below recommended values only in the control treatment, indicating the need for complementation with fertilization, despite the high soil $\mathrm{K}$ content $\left(0.5 \mathrm{cmol}_{\mathrm{c}} \mathrm{dm}^{-3}\right)$.

Table 3. Effect of biofertilizer application on leaf mineral concentration in three different phenological stages, and on pear fruit mineral concentration at commercial harvest (90 days after application).

\begin{tabular}{|c|c|c|c|c|c|c|c|c|c|c|c|}
\hline \multirow{2}{*}{ Treatment } & \multicolumn{6}{|c|}{ Macronutrients ( $\mathrm{g} \mathrm{kg}^{-1}$ dry matter) } & \multicolumn{5}{|c|}{ Micronutrients ( $\mathrm{mg} \mathrm{kg}^{-1}$ dry matter) } \\
\hline & $\mathrm{N}$ & $\mathrm{P}$ & $\mathrm{K}$ & $\mathrm{Ca}$ & $\mathrm{Mg}$ & $\mathrm{S}$ & $\mathrm{Fe}$ & $\mathrm{Mn}$ & $\mathrm{Cu}$ & $\mathrm{Zn}$ & B \\
\hline \multicolumn{12}{|c|}{ Mature leaves (July $\left.2^{\text {nd }} 2014\right)-30$ DAA } \\
\hline Control & 21.8 & 1.3 & 5.5 & 11.6 & 3.6 & 1.1 & 33 & 34 & 118 & 30 & 23 \\
\hline Biofertilizer $^{1}$ & 22.3 & 1.4 & 7.5 & 12.1 & 2.9 & 1.2 & 39 & 22 & 121 & 57 & 22 \\
\hline Significance $^{2}$ & ns & $*$ & $* *$ & ns & $*$ & ns & $\mathrm{ns}$ & $* *$ & ns & $* *$ & $\mathrm{~ns}$ \\
\hline \multicolumn{12}{|c|}{ Initial leaf senescence (Oct. $\left.2^{\text {nd }} 2014\right)-120$ DAA } \\
\hline Control & 19.6 & 1.4 & 5.2 & 15.7 & 3.3 & 1.3 & 52 & 32 & 222 & 77 & 29 \\
\hline Biofertilizer $^{1}$ & 21.1 & 1.4 & 6.6 & 16.3 & 2.7 & 1.3 & 46 & 16 & 205 & 79 & 28 \\
\hline Significance $^{2}$ & ns & ns & ns & ns & $*$ & ns & $*$ & $* *$ & $*$ & ns & $\mathrm{ns}$ \\
\hline \multicolumn{12}{|c|}{ Post-abscision leaves (Nov. $5^{\text {th }}$ and Dec. $\left.10^{\text {th }} 2014\right)-150$ and 180 DAA } \\
\hline Control & 13.8 & 1.1 & 5.4 & 17.7 & 3.4 & 1.2 & 169 & 39 & 251 & 77 & 37 \\
\hline Biofertilizer $^{1}$ & 14.3 & 1.2 & 8.5 & 18.8 & 2.7 & 1.2 & 140 & 18 & 260 & 92 & 39 \\
\hline Significance ${ }^{2}$ & $\mathrm{~ns}$ & ns & $*$ & ns & $* *$ & ns & $\mathrm{ns}$ & $* * *$ & $\mathrm{~ns}$ & ns & $\mathrm{ns}$ \\
\hline \multicolumn{12}{|c|}{ Commercial fruit (Sept. $\left.3^{\text {rd }} 2014\right)-90$ DAA } \\
\hline Control & 2.62 & 0.38 & 3.36 & 0.30 & 0.25 & 0.20 & 6 & 1 & 21 & 4 & 27 \\
\hline Biofertilizer $^{1}$ & 2.77 & 0.45 & 4.05 & 0.32 & 0.29 & 0.20 & 5 & 1 & 26 & 5 & 14 \\
\hline Significance $^{2}$ & $\mathrm{~ns}$ & $\mathrm{~ns}$ & $\mathrm{~ns}$ & $\mathrm{~ns}$ & $\mathrm{~ns}$ & $\mathrm{~ns}$ & $\mathrm{~ns}$ & ns & $\mathrm{ns}$ & ns & $* *$ \\
\hline
\end{tabular}

${ }^{1}$ Biofertilizer applied at $30 \mathrm{~m}^{3} \mathrm{ha}^{-1}$ dose on June 2nd 2014. ${ }^{2} \mathrm{~ns}$, *, ** and ***: not significant, significant for $p<0.05, p<0.01$ and $p<0.001$, respectively. 
Although leaves were thoroughly washed prior to analysis, the high leaf $\mathrm{Cu}$ concentration is most likely derived from the continued use of cupric fungicides in the control of diseases (REGIONE EMILIAROMAGNA, 2013), leading to leaf $\mathrm{Cu}$ uptake. These treatments are performed even during leaf senescence to prevent pathogens from penetrating the abscission septa. Toselli et al. (2002), also in Emilia Romagna conditions, recorded leaf $\mathrm{Cu}$ and $\mathrm{Zn}$ concentrations reaching up to $500 \mathrm{mg} \mathrm{kg}^{-1}$ each in Conference and Abbé Fétel pears during summer.

Excess $\mathrm{Cu}$ can prevent $\mathrm{Fe}$ absorption and translocation to shoots, which could be an explanation for the low leaf $\mathrm{Fe}$ concentration found in this experiment (AZEEZ et al., 2015; ADREES et al., 2015). The mechanisms behind this antagonistic effect can be related to the saturation of negative charges of root apoplastic environment by $\mathrm{Cu}$. Although a clear decrease of leaf $\mathrm{Fe}$ concentration as a response of increasing soil $\mathrm{Cu}$ concentration was found in grapevine (TOSELLI et al., 2009), this was not observed in pear, where increasing

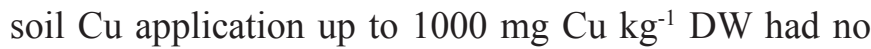
effect on leaf $\mathrm{Fe}$ concentration (TOSELLI et al., 2008). In addition, Fe deficiencies appear often in sub-alkaline pH (BRUMBAROVA et al., 2015), such as that of this study, as a consequence of $\mathrm{Fe}$ insolubilization.
Biofertilizer application increased leaf $\mathrm{K}, \mathrm{P}$ and $\mathrm{Zn}$ concentration as compared to control (Table 3). This effect may have reduced $\mathrm{Mg}$ and $\mathrm{Mn}$ absorption due to antagonism caused by competitive inhibition derived from $\mathrm{K}$ and Zn absorption (TOSELLI et al., 2002). This behavior was evidenced by the strong negative correlation between $\mathrm{K}$ and $\mathrm{Mg}(-0.81)$ and moderate negative correlation between $\mathrm{Zn}$ and $\mathrm{Mn}(-0.65)$. No effect of treatments on leaf $\mathrm{N}, \mathrm{Ca}, \mathrm{S}$ and $\mathrm{B}$ concentration was observed.

Overtime, decrease in $\mathrm{N}$ concentration and increase in $\mathrm{Ca}, \mathrm{Fe}, \mathrm{Cu}$ and $\mathrm{B}$ concentration for both treatments during the growing season were observed. P, $\mathrm{K}, \mathrm{Mg}$ and $\mathrm{S}$ concentrations were stable (Table 4). $\mathrm{Zn}$ concentration increased only in control, while its level remained stable (and relatively higher) in plants of treated plots. Similarly, Baldi et al. (2014), worked with nectarine trees, which belongs to the Rosaceae family, the same family of pear trees, reported, between mature stage and post-abscission, increase in $\mathrm{P}, \mathrm{Ca}, \mathrm{Mg}, \mathrm{Fe}$ and $\mathrm{Mn}$ concentration per leaf area, and reduction in $\mathrm{N}$, $\mathrm{K}$ and $\mathrm{Zn}$ concentration in the same period, while $\mathrm{Cu}$ concentration remained stable.

Table 4. Leaf nutrient concentration of 12-year old pear trees according to the phonological stage.

\begin{tabular}{ccccccccccccc}
\hline \multirow{2}{*}{ Phenological stage $^{1}$} & \multicolumn{1}{c}{ Macronutrients $\left(\mathrm{g} \mathrm{kg}^{-1}\right.$ dry matter $)$} & \multicolumn{7}{c}{ Micronutrients $\left(\mathrm{mg} \mathrm{kg}^{-1}\right.$ dry matter $)$} \\
& $\mathrm{N}$ & $\mathrm{P}$ & $\mathrm{K}$ & $\mathrm{Ca}$ & $\mathrm{Mg}$ & $\mathrm{S}$ & $\mathrm{Fe}$ & $\mathrm{Mn}$ & $\mathrm{Cu}$ & $\mathrm{Zn}$ & $\mathrm{B}$ \\
\hline & & \multicolumn{1}{c}{ Control } \\
\hline Mature leaves & $21.8 \mathrm{a}$ & 1.3 & 5.5 & $11.6 \mathrm{~b}$ & 3.6 & 1.1 & $33 \mathrm{~b}$ & 34 & $117 \mathrm{~b}$ & $30 \mathrm{~b}$ & $23 \mathrm{~b}$ \\
Initial leaf senescence & $19.6 \mathrm{a}$ & 1.4 & 5.2 & $15.7 \mathrm{a}$ & 3.3 & 1.3 & $52 \mathrm{~b}$ & 32 & $222 \mathrm{a}$ & $77 \mathrm{a}$ & $29 \mathrm{ab}$ \\
Post-abscision leaves & $13.8 \mathrm{~b}$ & 1.1 & 5.4 & $17.7 \mathrm{a}$ & 3.4 & 1.2 & $169 \mathrm{a}$ & 39 & $251 \mathrm{a}$ & $77 \mathrm{a}$ & $37 \mathrm{a}$ \\
\hline Significance & $* * *$ & $\mathrm{~ns}$ & $\mathrm{~ns}$ & $* * *$ & $\mathrm{~ns}$ & $\mathrm{~ns}$ & $* *$ & $\mathrm{~ns}$ & $* *$ & $* *$ & $* *$ \\
\hline & & \multicolumn{1}{c}{ Biofertilizer } \\
\hline Mature leaves & $22.3 \mathrm{a}$ & 1.4 & 7.5 & $12.1 \mathrm{~b}$ & 2.9 & 1.2 & $39 \mathrm{~b}$ & $22 \mathrm{a}$ & $121 \mathrm{~b}$ & 57 & $22 \mathrm{~b}$ \\
Initial leaf senescence & $21.1 \mathrm{a}$ & 1.4 & 6.6 & $16.3 \mathrm{a}$ & 2.7 & 1.3 & $46 \mathrm{~b}$ & $16 \mathrm{~b}$ & $205 \mathrm{a}$ & 79 & $28 \mathrm{ab}$ \\
Post-abscision leaves & $14.3 \mathrm{~b}$ & 1.2 & 8.5 & $18.8 \mathrm{a}$ & 2.7 & 1.2 & $140 \mathrm{a}$ & $18 \mathrm{ab}$ & $260 \mathrm{a}$ & 92 & $39 \mathrm{a}$ \\
\hline Significance & $* * *$ & $\mathrm{~ns}$ & $\mathrm{~ns}$ & $* *$ & $\mathrm{~ns}$ & $\mathrm{~ns}$ & $* * *$ & $*$ & $* *$ & $\mathrm{~ns}$ & $* *$ \\
\hline
\end{tabular}

${ }^{1}$ Sampling dates: mature leaves: July $2^{\text {nd }} 2014$ - 30 DAA; initial senescence leaves: Oct. $2^{\text {nd }} 2014$ - 120 DAA; post-abscission leaves: average of samplings performed on Nov. $5^{\text {th }}$ and Dec. $10^{\text {th }} 2014-150$ and 180 DAA. ${ }^{2}$ Liquid biofertilizer applied at $30 \mathrm{~m}^{3}$ ha ${ }^{-1}$ dose on June $2^{\text {nd }} 2014$. ${ }^{3} \mathrm{~ns}, *{ }^{*}, *$ and $* * *$ : not significant, significant for $p<0.05, p<0.01$ and $p<0.001$, respectively. Averages followed by the same letter are not statistically different.

$\mathrm{N}$ concentration reduction reflects nutrient translocation to storage organs (branches, stem and roots) at the end of the growing season, since during senescence, the transport of soluble nutrients is facilitated (QUARTIERI et al., 2002; ENGELS et al., 2012). Leaf remobilization in late summer/autumn in pear is high for N, K, P, and Zn (QUARTIERI et al., 2002; NETO et al., 2008). The increase in leaf $\mathrm{Ca}$ and micronutrient concentration is a result of their low mobility in the plant, while the possibility that plants have continued to uptake these nutrients during fall/winter should not be disregarded, consequently, their leaf concentration increased (ENGELS et al., 2012). 


\section{Yield and fruit quality}

Considering the average of treatments, fruit yield increased by $28 \%$ in plants treated with biofertilizer compared to control (5.9 $\mathrm{t} \mathrm{ha}^{-1)}$ (Table 5). The percentage of commercial fruits remained stable $(72 \%$ and $73 \%$ ), regardless of treatment. Fruit firmness and titratable acidity were not affected by treatments while a slight reduction in total soluble solids (TSS) and dry matter was observed in fruits from plants treated with biofertilizer (Table 5). TSS values are similar to those observed by Sorrenti et al. (2012), but their reduction by the biofertilizer application makes fruits less sweet, which could negatively impact their organoleptic quality. The average larger fruit production may have led to the dilution of sugars and other organic compounds, as also suggested by Lemiska et al. (2014) in strawberry and also verified by Amiri and Fallahi (2009) in apple submitted to different cow manure and poultry manure application rates.

Table 5. Effect of biofertilizer application on yield and fruit quality of 12-year old pear trees at commercial harvest (90 days after application).

\begin{tabular}{ccccccc}
\hline \multirow{2}{*}{ Treatment } & Yield & \multicolumn{4}{c}{ Fruit qualitative assessments } \\
& $\begin{array}{c}\text { Cotal } \\
\left(\mathrm{t} \mathrm{ha}^{-1}\right)\end{array}$ & $\begin{array}{c}\text { Commercial } \\
\left(\mathrm{t} \mathrm{ha}^{-1}\right)\end{array}$ & $\begin{array}{c}\text { Firmness } \\
(\mathrm{kg})\end{array}$ & $\begin{array}{c}\text { TSS } \\
\left({ }^{\circ} \mathrm{Brix}\right)\end{array}$ & $\begin{array}{c}\text { Titratable acidity } \\
\left(\mathrm{g} \mathrm{l}^{-1} \text { malic acid }\right)\end{array}$ & $\begin{array}{c}\text { Dry matter } \\
(\%)\end{array}$ \\
\hline Control & 20.8 & $14.4(73 \%)$ & 4.08 & 13.8 & 2.20 & 17.0 \\
Biofertilizer $^{1}$ & 26.7 & $19.1(72 \%)$ & 4.10 & 12.0 & 2.24 & 15.6 \\
\hline Significance $^{2}$ & & & $\mathrm{~ns}$ & $*$ & $\mathrm{~ns}$ & $*$ \\
\hline
\end{tabular}

${ }^{1}$ Biofertilizer applied at $30 \mathrm{~m}^{3}$ ha- dose on June $2^{\text {nd }} 2014 .{ }^{2} \mathrm{~ns}$ and $*$ : not significant and significant for $p<0.05$, respectively.

Regarding fruit nutrient concentration, there were no differences, except for $\mathrm{B}$, which was lower in the biofertilizer treatment (Table 3). Adequate B content is important for membrane integrity and may help preventing browning disorders during post-harvest conservation (HERRERA-RODRÍGUEZ et al., 2010; GANIE et al., 2013); however, this effect was not verified for fruit firmness (Table 5). Large fruit production could explain the decrease in fruit $\mathrm{B}$ concentration in treated plants, as B suffered a dilution due to the high number of fruits. This is a hypothesis, in part supported by a previous study on Turkish Deveci pear that showed higher B concentration in fruit than in leaves due to the translocation of both soil and leaf-applied B to fruits (GÜREL; BAŞAR, 2016). This implies that the amount of $\mathrm{B}$ applied was not adequate for the orchard demand. In addition, in tomato, B deficiency altered B distribution with greater concentration in stem and petiole than in fruit cluster and leaves (CHOI et al., 2015).

\section{Conclusions}

Biofertilizer application resulted in increased soil $\mathrm{N}$ availability, in synchrony with plant demand, but without effect on leaf $\mathrm{N}$ content in the various phases of the growth cycle.

Biofertilizer application resulted in higher leaf $\mathrm{K}$ and $\mathrm{Zn}$ content, which caused reduction in $\mathrm{Mg}$ and $\mathrm{Mn}$ contents.
Changes in leaf nutrient concentrations promoted by biofertilizer application reduced the TSS of fruits, influencing their quality.

\section{Acknowledgments}

This work was supported by CAPES (Coordination for the Improvement of Higher Education Personnel - Brazilian Ministry of Education). The authors thank Azienda Agricola Lodi Gianni and Riccardo of Gorgo (Ferrara, Italy), for hosting the trial.

\section{References}

ADREES, M.; ALI, S.; RIZWAN, M.; IBRAHIM, M.; ABBAS, F.; FARID, M.; ZIA-UR-REHMAN, M.; IRSHAD, M.K.; BHARWANA, S.A. The effect of excess copper on growth and physiology of important food crops: a review. Environmental Science and Pollution Research, Landsberg, v.22, p. 8148-8162, 2015.

ALENCAR, T.L.; CHAVES, A.F.; SANTOS, C.L.A.; JÚNIOR, R.N.A.; MOTA, J.C.A. Atributos físicos de um cambissolo cultivado e tratado com biofertilizante na Chapada do Apodi, Ceará. Revista Brasileira de Ciência do Solo, Viçosa, MG, v.39, p. 737-749, 2015. 
ÁLVAREZ-FERNÁNDEZ， A.; PÉREZ-SANZ, A.; LUCENA, J.J. Evaluation of effect of washing on mineral analysis of orange and peach leaves sprayed with seaweed extracts enriched with iron. Communications in Soil Science and Plant Analysis, London, v.32, n.12, p.170-257, 2001.

AMIRI, M. E.; FALLAHI, E. Impacto of animal manure on soil chemistry, mineral nutrients, yield, and fruit wuality in 'Golden Delicious'apple. Journal of Plant Nutrition, Philadelphia, v.32, p. 610-617, 2009.

ANDERSON, J.P.A.; DOMSCH, K.H. A physiological method for the quantitative measurement of microbial biomass in soils. Soil Biology and Biochemistry, Oxford, Great Britain, v.10, n.3, p.215-221, 1978.

AZEEZ, M.O.; ADESANWO, O.O.; ADEPETU, J.A. Effect of cooper $(\mathrm{Cu})$ application on soil available nutrients and uptake. African Journal of Agricultural Research, Nairobi, v.10, n.5, p.359-364, 2015.

BALDI, E.; MARCOLINI, G.; QUARTIERI, M.; SORRENTI, G.; TOSELLI, M. Effect of organic fertilization on nutrient concentration and accumulation in nectarine (Prunus persica var. nucipersica) trees: the effect of rate of application. Scientia Horticulturae, New York, v.179, p.174-179, 2014.

BALOTA, E.L.; AULER, P.A.M. Soil microbial biomass under different management and tillage systems of permanent intercropped cover species in an orange orchard. Revista Brasileira de Ciência do Solo, Viçosa, MG, v.35, p.1873-1883, 2011.

BARRETO,P.A.B; GAMA-RODRIGUES, E.F.; GAMARODRIGUES, A.C.; BARROS, N.D.; FONSECA, S. Atividade microbiana, carbono e nitrogênio da biomassa microbiana em plantações de eucalipto, em sequência de idades. Revista Brasileira de Ciência do Solo, Viçosa, MG, v.32, p.611-619, 2008.

BOONE, R.D.; GRIGAL, D.F.; SOLLINS, P.; AHRENS, R.J.; ARMSTRONG, D.E. Soil sampling, preparation, archiving, and quality control. In: ROBERTSON, G.P.; COLEMAN, D.C.; BLEDSOE, C.S.; SOLLINS, P. (ed.). Standard soil methods for long-term ecological research. Oxford: University Press, 1999. p.3-28.

BRUMBARONA, T.; BAUER, P.; IVANOV, R. Molecular mechanisms governing Arabidopsis iron uptake. Trends in Plant Science, Cambridge, v.20, n.2, p. 124-133, 2015.
CARRANCA, C.; BRUNETTO, G.; TAGLIAVINI, M. Nitrogen nutrition of fruit trees to reconcilie productivity and environmental concerns. Plants, Basel, v.7, n.1, p.E4, 2018.

CHOI, E.Y.; PARK, H.I.; JU., J.H; YOON, Y.H. Boron availability alters its distribution in plant parts of tomato. Horticulture, Environment and Biotechnology, Singapore, v.56, n.2. p. 145-151, 2015.

CIHANGIR, H.; OKTEM, A. The effect of different organic nutrients on some quality properties of popcorn (Zea mays L. everta). Asian Food Science Journal, London, v.7, n.2, p. 1-9, 2019.

DĘBSKA， B.; DLUGOSZ, J.; PIOTROWKADLUGOSZ, A.; BANACH-SZOTT, M. The impact of a bio-fertilizer on the soil organic matter status and carbon sequestration - results from a field-scale study. Journal Soils Sediments, Landsberg, v.16, p. 2335-2343, 2016.

DI, H.J.; CAMERON, K.C.; SHEN, J.P.; WINEFIELD, C.S.; O'CALLAGHAN, M.; BOWATTE, S,; HE, J.Z. Nitrification driven by bacteria and not archaea in nitrogen-rich grassland soils. Nature Geoscience, London, v.2, n.9, p.621-624, 2009.

DIACONO, M.; MONTEMURRO, F. Long-term effects of organic amendments on soil fertility - a review. Agronomy for Sustainable Development, Les Ulis, v.30, n.2, p.401-422, 2010.

ENGELS, C.; KIRKBY, E.; WHITE, P. Mineral nutrition, yield and source-sink relationships. In: MARSCHNER, P. Mineral nutrition of higher plants. $3^{\text {rd }}$ ed. Cambridge: Academic Press, 2012. p.85-133.

FAO - Food and Agriculture Organization of the United Nations. Revised legend of the soil map of the world. Rome: FAO, 1988. [World Soil Resources Report, 60].

GAMA-RODRIGUES, E.F.; GAMA-RODRIGUESA.C. Microbial biomass and nutrient cycling. In: SANTOS, G.A.; SILVA, L.S.; CANELLAS, L.P.; CAMARGO, F.A.O. Foundations of soil organic matter: tropical and subtropical ecosystems. $2^{\text {nd }}$ ed. Porto Alegre: Ed, Metrópole, 2008. p.159-170.

GANIE, M.A.; AKHTER, F.; BHAT, M.A.; MALIK, A.R.; JUNAID, J.M.; SHAH, M.A.; BHAT, A.H.; BHAT, T.A. Boron - a critical nutrient element for plant growth and productivity with reference to temperate fruits. Current Science, Bangalore, v.104, n.1,p. 76-85, 2013. 
GÜREL, S; BAȘAR, H. Effect of application of boron with iron and zinc on the content of pear trees. Notulae Botanicae Horti Agrobotanici, Cluj-Napoca, v.44, n.1, p.125-132, 2016

HAYNES, R.J. Labile organic matter fractions as central components of the quality of agricultural soils: an overview. Advances in Agronomy, San Diego, v.85, p. 221-268, 2005.

HERRERA-RODRÍGUEZ, M.B.; GONZÁLEZFONTES, A.; REXACH, J.; CAMACHO-CRISTÓBAL, J.J.; MALDONADO, J.M.; NAVARRO-GOCHICOA, M.T. Role of boron in vascular plants and response mechanisms to boron stresses. Plant Stress, v.2, n.4, p.115-122, 2010.

JENKINSON, D.S.; POWLSON, D.S. The effects of biocidal treatments on metabolism in soil $-\mathrm{V}$ : a method for measuring soil biomass. Soil Biology and Biochemistry, Oxford, v.8, n.3, p.209-213, 1976.

JORDÁN, A.; ZAVALA, L.M.; GIL, J. Effects of mulching on soil physical properties and runoff under semi-arid conditions in southern Spain. Catena, Amsterdam, v.81, n.1, p. 77-85, 2010.

KINGSTON, H.M. Method 3052. Microwave assisted acid digestion of siliceous and organically-based matrices. Washington: U.S. Environmental Protection Agency Quarterly Report, 1988.

KUKAL, S.S.; REHANNA-RASOOL; BENBI, D.K. Soil organic carbon sequestration in relation to organic and inorganic fertilization in rice-wheat and maizewheat systems. Soil \& Tillage Research, Amsterdam, v.102, p.87-92, 2009.

LAL, R. Soil quality impacts of residue removal for bioethanol production. Soil and Tillage Research, Amsterdam, v.102, n.2, p.233-241, 2009.

LAVELLE, P. Ecological challenges for soil Science. Soil Science, Baltimore, v.165, n.1, p.73-86, 2000.

LEMISKA, A.; PAULETTI, V.; CUQUEL, F.L.; ZAWADNEAK, M.A.C. Produção e qualidade da fruta do morangueiro sob influência da aplicação de boro. Ciência Rural, Santa Maria, v. 44, n.4, p. 622-628, 2014.

LOURENZI, C.R.; SCHERER, E.E.; CERETTA, C.A.; TIEC HER, T.L.; CANCIAN, A.; FERREIRA, P.A.A.; BRUNETTO, G. Atributos químicos de Latossolo após sucessivas aplicações de composto orgânico de dejeto líquido de suínos. Pesquisa Agropecuária Brasileira, Brasília, DF, v.51, n.3, p.233-241, 2016.
MARROCOS, S.T.P.; JUNIOR, J.N.; GRANGEIRO, L.C.; AMBROSIO, M.M.Q.; CUNHA, A.P.A. Composição química e microbiológica de biofertilizantes em diferentes tempos de decomposição. Revista Caatinga, Mossoró, v. 25, n.4, p. 34-43, 2012.

MINOGUE, P.J.; OSIECKA, A.; MACKOWIAK, C.L.; NOWAK, J. Leaching potential with diammonium phosphate and poultry litter fertilization of young pine plantations in the Florida Sandhills. Southern Journal of Applied Forestry, Washington, v.36, n.4, p.181-190, 2012.

MÖLLER, K.; MÜLLER, T. Effects of anaerobic digestion on digestate nutrient availability and crop growth: A review. Engineering in Life Sciences, Weinheim, v. 12, n.3, p. 242-257, 2012.

NARDI, S.; MORARI, F.; BERTI, A.; TOSONI, M.; GIARDINI, L. Soil organic matter properties after 40 years of different use of organic and mineral fertilizers. European Journal of Agronomy, Amsterdam, v.21, p.357-367, 2004.

NAZ; M.Y.; SULAIMAN, S.A. Slow release coating remedy for nitrogen loss from conventional urea: a review. Journal of Controlled Release, Amsterdam, v.225, p. 109-120, 2016.

NETO, C.; CARRANCA, C.; CLEMENTE, J.; DE VARENNES, A. Nitrogen distribution, remobilization and recycling in young orchard of non-bearing 'Rocha' pear trees. Scientia Horticulturae, v.118, p.299-307, 2008.

NIE, J.; FENG, H.; WITHERELL, B.B.; ALEBUS, M.; MAHAJAN, M.D.; ZHANG,W.; YU, L. Causes, assessment, and treatment of nutrient $(\mathrm{N}$ and $\mathrm{P})$ pollution in rivers, estuaries, and coastal waters. Current Pollution Reports, Cham, v.4, n.2, p.154-161, 2018.

NIINEMETS, Ü. Leaf age dependent changes in withincanopy variation in leaf functional traits: a meta-analysis. Journal of Plant Research, Tokyo, v. 129, n.3, p. 313 $338,2016$.

OLDFIELD, E.E.; WOOD, S.A.; BRADFORD, M.A. Direct effects of soil organic matter on productivity mirror those observed with organic amendments. Plant and Soil, Dordrecht, v.423, n.1-2, p.363-373, 2018. 
OLIVEIRA， S.V.W.B.; LEONETI，A.B.; CALDO, G.M.M.; OLIVEIRA, M.M.B. Generation of bioenergy and biofertilizer on a sustainable rural property. Biomass and Bioenergy, Amsterdam, v.35, n.7, p.2608-2618, 2011.

OMARA, P.; AULA, L.; RAUN, W.R. Nitrogen uptake efficiency and total soil nitrogen accumulation in longterm beef manure and inorganic fertilizer application. International Journal of Agronomy, Cairo, v.2019, p.1-6, 2019.

PEEL, M.C.; FINLAYSON, B.L.; MCMAHON, T.A. Updated world map of the Koppen-Geiger climate classification. Hydrology and Earth System Sciences, Katlenburg-Lindau, v.4, p. 439-473, 2007.

QUARTIERI, M.; MILLARD, P.; TAGLIAVINI, M. Storage and remobilization of nitrogen by pear (Pyrus communis L.) trees as affected by timing of $\mathrm{N}$ supply. European Jornal of Agronomy, Oxford, v.17, n.2, p.105-110, 2002.

RAHEEM, A. HASSAN, M.Y.; SHAKOOR, R. Bioenergy from anaerobic digestion in Pakistan: Potential, development and prospects. Renewable and Sustainable Energy Reviews, Oxford, v.59, p.264-275, 2016.

REGIONE EMILIA-ROMAGNA. Specifications on integrated production: summary of techniques for sanitary defense and weeding. Romagna: Programma di Sviluppo Rurale dell'Emilia-Romagna, 2013.

ROCHETTE, P.; ANGERS, D.A.; CHANTIGNY, M.H.; GASSIER, M.O.; MACDONALD, J.D.; PELSTER, D.E.; BERTRAND, N. $\mathrm{NH}_{3}$ volatilization, soil concentration and soil $\mathrm{pH}$ following subsurface banding of urea at increasing rates. Canadian Journal of Soil Science, Ottawa, v.93, n.2, p.261-268, 2013.

SCHUMAN, G.E.; STANLEY, M.A.; KNUDSEN, D. Automated total nitrogen analysis of soil and plant samples. Soil Science Society of America Journal, Madison, v.3, p.480-481, 1973.

SERVIZIO GEOLOGICO, E SISMICO E DEI SUOLI. Soil cartography. 2006-2013. Emilia-Romagna, 2014. Disponível em: https://applicazioni.regione.emiliaromagna.it/cartografia_sgss/user/viewer.jsp?service $=$ pe dologia\&bookmark=1\%22. Accesso em: 15 oct. 2014.
SORRENTI, G.; TOSELLI, M.; MARANGONI, B. Use of compost to manage Fe nutrition of pear trees grown in calcareous soil. Scientia Horticulturae, New York, v.136, p.87-94, 2012.

SUGAR, D.; RIGHETTI, T.L.; SANCHEZ, E.E.; KHEMIRA, H. Management of nitrogen and calcium in pear trees for enhancement of fruit resistance to postharvest decay. HortTechnology, Alexandria, v. 2, n.3, p.382-387, 1992.

SVANBÄCK, A.; MCCRACKIN, M.L.; SWANEY, D.P.; LINEFUR, H.; GUSTAFSSON, B.G.; HOWARTH, R.W.; HUMBORG, C. Reducing agricultural nutrient surpluses in a large catchment - Links to livestock density. Science of the Total Environment, Amsterdam, v.648, p.1549-1559, 2019.

TAMBONE, F.; GENEVINI, P.; D'IMPORZANO, G.; ADANI, F. Assessing amendment properties of digestate by studying the organic matter composition and the degree of biological stability during the anaerobic digestion of the organic fraction of MSW. Bioresources Technology, Oxford, v.100, n.12, p. 3140-3142, 2009.

TILMAN, D.; CLARK, M. Food, agriculture \& the environment: Can we feed the world \& save the earth? Daedalus, Cambridge, v.144, n.4, p.8-23, 2015.

TOSELLI M., BALDIE., MARCOLINIG., MALAGUTI D., QUARTIERI M., SORRENTI G. MARANGONI B. Response of potted grapevines to increasing soil copper concentration. Australian Journal of Grape and Wine Research, Oxford, v.15, p. 85-92, 2009.

TOSELLI, M.; BALDI, E.; MARCOLINI, G.; MALAGUTI, D.; QUARTIER,I M.; SORRENTI, G.; MARANGONI, B. Response of potted pear trees to increasing copper concentration in sandy and clay-loam soils. Journal of Plant Nutrition, Philadelphia, v.31, p.2089-2104, 2008.

TOSELLI, M.; MAZZANTI, F.; MARANGONI, B.; TAGLIAVINI, M.; SCUDELLARI, D. Determination of leaf standards for mineral diagnosis in pear orchards in the Po valley, Italy. Acta Horticulturae, The Hague, v.596, p.665-669, 2002. 
UNGARO, F.; CALZOLARI, C.; TAROCCO, P.; GIAPPONESI, A.; SARNO, G. Soil organic matter in the soils of Emilia Romagna plain (Northen Italy): knowledge and management policies. In: OEDC. Soil organic carbon and agriculture: developing indicators for policy analisys. Paris, 2003. Disponível em: http:// www.oecd.org/tad/env/indicators. Acesso em: 18 feb. 2016.

VENTURA, M.; ZHANG, C.; BALDI, E.; FORNASIER, F.; SORRENTI, G.; PANZACCHI, P.; TONON, G. Effect of biochar addition on soil respiration partitioning and root dynamics in an apple orchard. European Journal of Soil Science, Oxford, v.65, p.86-195, 2013.
VERONEZE, M.L.; SCHWANTES, D.; GONÇALVES, A.C.; RICHART, A.; MANFRIN, J.; DA PAZ SCHILLER, A.; SCHUBA, T.B. Production of biogas and biofertilizer using anaerobic reactors with swine manure and glycerine doses. Journal of Cleaner Production, Amsterdam, v.213, p.176-184, 2019.

VOLK, M.; LIERSCH, S.; SCHMIDT, G. Towards the implementation of the European Water Framework Directive: lessons learned from water quality simulations in an agricultural watershed. Land Use Policy, Kidlington, v.26, n.3 p.580-588, 2009. 